\title{
Low Back Pain in Operating Room Nurses and Its Associated Factors
}

\author{
Ikbal Cavdar ${ }^{1}$, Ahmet Karaman ${ }^{2}$, \\ Yasemin Ozhanli ${ }^{3}$, Ayfer Ozbas ${ }^{4}$
}

\begin{abstract}
Objective: To determine the presence of low back pain and the associated factors in operating room nurses.

Methods: The population of the descriptive study consists of 133 operating room nurses working in the operating rooms of five major hospitals located in Istanbul, and the study sample consists of 96 operating room nurses who are not on leave or sick leave between July-2016 to February 2017. Data were collected via a question form prepared by the researchers.

Results: It was determined that more than half of the operating room nurses forming the sample group had low back pain and that it is affected from the practices of operating room nurses during a shift, which may cause physical strain such as year of working as an operating room nurse, bending and staying in the same position for a long time, holding an instrument for a long time, rotational movement inadequate to body mechanics, lifting/carrying heavy medical items and pushing/pulling heavy medical equipment.

Conclusion: Majority of operating room nurses had low back pain and it was associated with coercive movements during surgery.
\end{abstract}

KEYWORDS: Low back pain, Occupational health, Operating room nurse, Risk factors.

How to cite this:

doi: https://doi.org/10.12669/pjms.36.6.2836

Cavdar I, Karaman A, Ozhanli Y, Ozbas A. Low Back Pain in Operating Room Nurses and Its Associated Factors. Pak J Med Sci. 2020;36(6):1291-1296. doi: https://doi.org/10.12669/pjms.36.6.2836

This is an Open Access article distributed under the terms of the Creative Commons Attribution License (http://creativecommons.org/licenses/by/3.0), which permits unrestricted use, distribution, and reproduction in any medium, provided the original work is properly cited.

\section{INTRODUCTION}

1. Ikbal Cavdar, MSc, $\mathrm{PhD}$

Professor,

2. Ahmet Karaman, MSc, PhD

3. Yasemin Ozhanli, MSc, PhD

4. Ayfer Ozbas, MSc, PhD,

Professor,

1-4: Surgical Nursing Department,

Florence Nightingale Faculty of Nursing,

Istanbul University-Cerrahpasa,

Istanbul, Turkey.

Correspondence:

Dr. Ahmet Karaman,

Department of Surgical Nursing,

Florence Nightingale Faculty of Nursing,

Istanbul University-Cerrahpasa,

Abide-i Hurriyet Street, 34381

Sisli, Istanbul, Turkey.

Email: ahmet.karaman@istanbul.edu.tr

* Received for Publication:

May 10, 2020

* Edited and Corrected:

* Accepted for Publication:

June 25, 2020

July 3, 2020
Anatomical, physiological, psychological and socio-cultural characteristics of healthcare professionals, along with working technique and physical characteristics of the working environment, negatively affect the musculoskeletal system. The prevalence of musculoskeletal system disorders is $5.7 \%$ in industrial workers while this rate increases to $8.8 \%$ in people working in hospitals.

Nurses, who have an important role among healthcare professionals, experience musculoskeletal system disorders, including upper back, neck, shoulder and joint pain. The most common musculoskeletal system problem observed in nurses is low back pain. ${ }^{2,3}$ Different studies in the literature evaluated one-year incidence of low back pain in nurses in various countries and found this rate to be $56.8 \%$ in China, 
$40.6 \%$ in Hong Kong, 59\% in Japan, 50.1\% in Tunisia and $40-50 \%$ in the United States of America. ${ }^{4}$ Even though there is no research in Turkey that assesses the rate of low back pain in nurses in a way that can be generalized to all nurses, there are studies performed with certain groups. Gul et al. (2014) found that $66.4 \%$ of nurses experience low back pain while Y1lmaz and Özkan (2008) found that $39.9 \%$ of nurses had low back pain. ${ }^{3,5}$

Nurses working in the operating room possess a greater risk in terms of musculoskeletal problems due to pulling and pushing gurneys, beds and other equipment, transferring the patient to the operating table or gurney, supporting an extremity for a long time and standing in the same position for a long time. ${ }^{2,3}$

Keeping in mind those risk factors about musculoskeletal problems in operating room nurses will increase workforce loss and costs by causing functional insufficiencies in the future, determining the risk factors for low back pain in operating room nurses and taking the necessary precautions are of vital importance. The study was conducted in order to determine the rate of low back pain in operating room nurses and its associated factors.

\section{METHODS}

The population of this descriptive study consisted of 133 nurses who worked in the operating rooms of five major hospitals in Istanbul. Rather than sampling, census was aimed. Inclusion criteria were determined as being working in the operating rooms of the study hospitals for at least six months, not being on leave/sick leave between July 2016 and February 2017 and volunteering to participate in the study. Because some nurses had taken a leave in the defined time period and some nurses declined to participate, $72.1 \%$ of the universe was reached and the study was completed with 96 operating room nurses.

Data were collected using a "Data Collecting Form" developed by the researchers in the light of the literature. ${ }^{2,3,5-9}$ The form consisted of four sections that questioned descriptive characteristics of the nurses, working conditions, the frequency of practices that may cause physical strain during work and the characteristics of low back pain encountered in operating room nurses. Data were collected using face-to-face interviewing technique on working days of operating room nurses and in time periods that won't interfere with the work order.
The data obtained from the study was analyzed with the Statistical Package for Social Science 21.0 packaged software. Frequency, percentage, mean, standard deviation, Chi-squared and student's $t$ test were used when appropriate. Results were evaluated with $95 \%$ confidence interval and $\mathrm{p}<0.05$ significance level.

Written approval from a faculty of medicine clinical research ethics committee (Approval Date and Number: 12.07.2016-A-24) and hospitals that the study was conducted in were obtained prior to the start of the study. Verbal and written consent was also obtained from nurses before data collecting tools were applied.

\section{RESULTS}

Out of operating room nurses that participated in the study, $52.2 \%$ were between $21-35$ years of age. $82.3 \%$ were female. $53.1 \%$ were married. $55.2 \%$ had a graduate degree and $47.9 \%$ had 11 years or more professional experience and $37.5 \%$ had been working has an operating room nurse for one to five years. About $72.9 \%$ did not smoke; $84.4 \%$ worked out regularly and $63.5 \%$ defined their health status as "well". About $43.8 \%$ had a responsibility for caring for a relative and/ or children or that required carrying weight outside working hours. $71.9 \%$ had normal BMI $\left(18.5 \mathrm{~kg} / \mathrm{m}^{2}<\mathrm{BMI}<25.0 \mathrm{~kg} / \mathrm{m}^{2}\right)$. Total time spent standing in one shift was found to be $6.5208 \pm 1.56931$ hours. $76 \%$ of operating room nurses took a break during work and time worked until a break was found to be $4.0411 \pm 1.16756$ hours.

Almost $28.1 \%$ of operating room nurses positioned a patient one to two times in one shift. $31.3 \%$ moved the patient from operating table to gurney one to two times in one shift. $56.3 \%$ of nurse leaned more than five times in one shift. $67.7 \%$ stood in the same position for a long time more than five times in one shift. 50.0\% held equipment for a long time more than five times in one shift. $33.3 \%$ supported any part of patient for a long time one to two times in one shift. $31.3 \%$ rotated backwards more than five times in one shift, 32.3\% of operating room nurses lifted/carried heavy medical equipment more than five times in one shift, while $34.4 \%$ pulled/pushed heavy medical equipment more than five times in one shift.

In this study $67.7 \%$ of operating room nurses who participated had low back pain at any time. $93.8 \%$ of those experienced low back pain in the past year, $87.7 \%$ experienced low back pain in the current year while $55.4 \%$ experienced low back pain on the day of the interview. 
Table-I: Comparison of the Frequency of Low Back Pain in Operating Room Nurses with Descriptive Characteristics and Working Conditions.

\begin{tabular}{|c|c|c|c|c|c|c|}
\hline \multirow[b]{2}{*}{ Characteristics } & \multicolumn{2}{|c|}{$\begin{array}{l}\text { Low Back Pain } \\
\text { Present }(n=65)\end{array}$} & \multicolumn{2}{|c|}{$\begin{array}{l}\text { Low Back Pain } \\
\text { Absent }(n=31)\end{array}$} & \multirow[t]{2}{*}{$X^{2} / t$} & \multirow[t]{2}{*}{$p$} \\
\hline & $n$ & $\%$ & $n$ & $\%$ & & \\
\hline Age (years) & & & & & $0.016^{\mathrm{a}}$ & 0.898 \\
\hline 21 to 35 & 36 & 69.2 & 16 & 30.8 & & \\
\hline 36 and older & 29 & 65.9 & 15 & 34.1 & & \\
\hline Marital Status & & & & & $0.203^{a}$ & 0.503 \\
\hline Married & 33 & 64.7 & 18 & 35.3 & & \\
\hline Single & 32 & 71.1 & 13 & 28.9 & & \\
\hline Total Time Worked as an Operating Room Nurse & & & & & $11.450^{\mathrm{a}}$ & $0.010^{*}$ \\
\hline Less than 1 year & 1 & 14.3 & 6 & 85.7 & & \\
\hline 1 to 5 years & 27 & 75.0 & 9 & 25.0 & & \\
\hline 6 to 10 years & 18 & 78.3 & 5 & 21.7 & & \\
\hline 11 years and above & 19 & 63.3 & 11 & 36.7 & & \\
\hline Smoking & & & & & 0.000 & 1.000 \\
\hline Yes & 18 & 69.2 & 8 & 30.0 & & \\
\hline No & 47 & 67.1 & 23 & 32.9 & & \\
\hline Regular Exercise & & & & & $0.991^{\mathrm{a}}$ & 0.319 \\
\hline Yes & 8 & 53.3 & 7 & 46.7 & & \\
\hline No & 57 & 70.4 & 24 & 29.6 & & \\
\hline $\begin{array}{l}\text { Responsibility that Requires Carrying Weight or } \\
\text { for Caring for Someone Outside Working Hours }\end{array}$ & & & & & $2.042^{\mathrm{a}}$ & 0.564 \\
\hline Never or rarely & 31 & 73.8 & 11 & 26.2 & & \\
\hline Sometimes & 22 & 64.7 & 12 & 35.3 & & \\
\hline Often & 5 & 71.4 & 2 & 28.6 & & \\
\hline Always & 7 & 53.8 & 6 & 46.2 & & \\
\hline BMI & & & & & $7.969^{a}$ & $0.047^{*}$ \\
\hline Underweight (<18.5 kg/m2) & 1 & 20.0 & 4 & 80.0 & & \\
\hline Normal $(18.5 \mathrm{~kg} / \mathrm{m} 2<\mathrm{BMI}<25.0 \mathrm{~kg} / \mathrm{m} 2)$ & 51 & 73.9 & 18 & 26.1 & & \\
\hline Overweight $(25.0 \mathrm{~kg} / \mathrm{m} 2<\mathrm{BMI}<30.0 \mathrm{~kg} / \mathrm{m} 2)$ & 12 & 57.1 & 9 & 42.9 & & \\
\hline Obese ( $\mathrm{BMI} \geq 30.0 \mathrm{~kg} / \mathrm{m} 2)$ & 1 & 100.0 & 0 & 0.0 & & \\
\hline Taking a break during work & & & & & $0.001^{\mathrm{a}}$ & 0.801 \\
\hline Yes & 50 & 68.5 & 23 & 31.5 & & \\
\hline No & 15 & 65.2 & 8 & 34.8 & & \\
\hline $\begin{array}{l}\text { Total Time Spent Standing During } \\
\text { One Shift (Hours) (Mean } \pm \text { Sd) }\end{array}$ & & & 6.6 & & $0.395^{\mathrm{b}}$ & 0.694 \\
\hline
\end{tabular}

$\mathrm{a}=$ Chi-squared test, $\mathrm{b}=$ Independent samples $\mathrm{t}$ test, ${ }^{*}=\mathrm{p}<0.05, \%=$ Given as line percentage,

Sd: Standard deviation, BMI: Body mass index.

The prevalence of low back pain was higher in nurses who worked as an operating room nurse for six to 10 years than others who worked for less than one year, one to five years and more than 11 years and the difference was significant $(p<0.05)$. Also, the prevalence of low back pain was significantly higher in operating room nurses with normal BMI when compared to nurses with BMI $<18.5 \mathrm{~kg} / \mathrm{m}^{2}$ and $25.0 \mathrm{~kg} / \mathrm{m}^{2}<\mathrm{BMI}<30.0 \mathrm{~kg} / \mathrm{m}^{2}$ $(\mathrm{p}<0.05)$ (Table-I).

Nurses who leaned more than five times in one shift experienced low back pain more frequently than nurses who leaned for three to five times in one shift, one to two times in one shift and never leaned. Nurses who stood in the same position for a long time three to five times in one shift had more back pain than other who stood in the same position for a long time more than five times, one to two times or never stood in the same position. Nurses who held equipment for a long time three to five times in one shift had more back pain than other who held equipment for a long time more than five times, one to two times or never held equipment for a long time. Finally, nurses who 
Table-II: Comparison of the Frequency of Low Back Pain in Operating Room Nurses with Practices that may Cause Physical Strain.

\begin{tabular}{|c|c|c|c|c|c|c|}
\hline \multirow[b]{2}{*}{ Expressions } & \multicolumn{2}{|c|}{$\begin{array}{l}\text { Low Back Pain } \\
\text { Present }(n=65)\end{array}$} & \multicolumn{2}{|c|}{$\begin{array}{l}\text { Low Back Pain } \\
\text { Absent }(n=31)\end{array}$} & \multirow[t]{2}{*}{$X^{2}$} & \multirow[t]{2}{*}{$p$} \\
\hline & $n$ & $\%$ & $n$ & $\%$ & & \\
\hline Positioning a patient & & & & & 2.787 & 0.426 \\
\hline More than 5 times a day & 8 & 72.7 & 3 & 27.3 & & \\
\hline 3 to 5 times a day & 15 & 75.0 & 5 & 25.0 & & \\
\hline 1 to 2 times a day & 20 & 74.1 & 7 & 25.9 & & \\
\hline Never & 22 & 57.9 & 16 & 42.1 & & \\
\hline Moving the patient from operating table to gurney & & & & & 3.708 & 0.295 \\
\hline More than 5 times a day & 7 & 63.6 & 4 & 36.4 & & \\
\hline 3 to 5 times a day & 13 & 86.7 & 2 & 13.3 & & \\
\hline 1 to 2 times a day & 21 & 70.0 & 9 & 30.0 & & \\
\hline Never & 24 & 60.0 & 16 & 40.0 & & \\
\hline Leaning & & & & & 15.078 & $0.002^{*}$ \\
\hline More than 5 times a day & 42 & 77.8 & 12 & 22.2 & & \\
\hline 3 to 5 times a day & 16 & 76.2 & 5 & 23.8 & & \\
\hline 1 to 2 times a day & 6 & 37.5 & 10 & 62.5 & & \\
\hline Never & 1 & 20.0 & 4 & 80.0 & & \\
\hline Standing in the same position for a long time & & & & & 17.661 & $0.001^{*}$ \\
\hline More than 5 times a day & 49 & 75.4 & 16 & 24.6 & & \\
\hline 3 to 5 times a day & 12 & 80.0 & 3 & 20.0 & & \\
\hline 1 to 2 times a day & 2 & 16.7 & 10 & 83.3 & & \\
\hline Never & 2 & 50.0 & 2 & 50.0 & & \\
\hline Holding equipment for a long time & & & & & 12.898 & $0.005^{*}$ \\
\hline More than 5 times a day & 37 & 77.1 & 11 & 22.9 & & \\
\hline 3 to 5 times a day & 17 & 81.0 & 4 & 19.0 & & \\
\hline 1 to 2 times a day & 8 & 38.1 & 13 & 61.9 & & \\
\hline Never & 3 & 50.0 & 3 & 50.0 & & \\
\hline Supporting any part of patient for a long time & & & & & 2.644 & 0.450 \\
\hline More than 5 times a day & 14 & 73.7 & 5 & 26.3 & & \\
\hline 3 to 5 times a day & 19 & 73.1 & 7 & 26.9 & & \\
\hline 1 to 2 times a day & 22 & 68.8 & 10 & 31.3 & & \\
\hline Never & 10 & 52.6 & 9 & 47.4 & & \\
\hline Rotating backwards & & & & & 14.953 & $0.002^{*}$ \\
\hline More than 5 times a day & 24 & 80.0 & 6 & 20.0 & & \\
\hline 3 to 5 times a day & 23 & 76.7 & 7 & 23.3 & & \\
\hline 1 to 2 times a day & 17 & 60.7 & 11 & 39.3 & & \\
\hline Never & 1 & 12.5 & 7 & 87.5 & & \\
\hline Lifting/carrying heavy medical equipment & & & & & 10.685 & $0.014^{*}$ \\
\hline More than 5 times a day & 24 & 77.4 & 7 & 22.6 & & \\
\hline 3 to 5 times a day & 18 & 78.3 & 5 & 21.7 & & \\
\hline 1 to 2 times a day & 19 & 65.5 & 10 & 34.5 & & \\
\hline Never & 4 & 30.8 & 9 & 69.2 & & \\
\hline Pulling/pushing heavy medical equipment & & & & & 10.862 & $0.012^{*}$ \\
\hline More than 5 times a day & 26 & 78.8 & 7 & 21.2 & & \\
\hline 3 to 5 times a day & 19 & 73.1 & 7 & 26.9 & & \\
\hline 1 to 2 times a day & 18 & 64.3 & 10 & 35.7 & & \\
\hline Never & 2 & 22.2 & 7 & 77.8 & & \\
\hline
\end{tabular}

$\mathrm{X}^{2}=$ Chi-squared test, ${ }^{*}=\mathrm{p}<0.05, \%=$ given as line percentage. 
rotated backwards more than 5 times in one shift experienced low back pain more frequently than nurses who rotated backwards for 3 to 5 times in one shift, one to two times in one shift and never rotated. All differences were statistically significant $(\mathrm{p}<0.05)$ (Table-II).

Similarly, operating room nurses who lifted/ carried heavy medical equipment 3 to 5 times in one shift had more back pain than other who stood in the same position for a long time more than 5 times, 1 to 2 times or never stood in the same position. Also, nurses who pulled/pushed heavy medical equipment more than 5 times in one shift experienced low back pain more frequently than nurses who pulled/pushed heavy medical equipment for three to five times in one shift one to two times in one shift and never pulled/pushed. These differences were statistically significant as well $(\mathrm{p}<0.05)($ Table-II).

\section{DISCUSSION}

Low back pain is one of the most common musculoskeletal problems observed among nurses. ${ }^{10,11}$ Different studies with nurses and healthcare professionals revealed that more than half of the participants experienced low back pain. ${ }^{2,3,5,6}$ Similar results were obtained with studies from China, Tunisia, the United Kingdom, Sweden, Iran, Italy, Hong Kong, Nigeria and Japan. ${ }^{4}$ Likewise, more than half of the nurses in the present study expressed having low back pain.

Age is among the individual risk factors that may cause low back pain. There was no statistically significant association between age and the prevalence of low back pain in this study. Even though there are studies in the literature indicating that age variable does not impact the prevalence of low back pain ${ }^{9,12,13}$, studies implicating the contrary are also present. ${ }^{6,10,11}$

Marital status variable did not cause a difference in the frequency of low back pain in the present study. Despite there are studies, which found that single individuals experience more low back pain than married individuals ${ }^{2,14}$, other studies support our findings. ${ }^{3,6,15}$

As the years worked increase, total exposure to risks in the workplace also increase, increasing the risk of associated health deterioration. In the present study, individuals who had been working for an operating room nurse were found to have more low back pain. Even though many studies performed with healthcare professionals ${ }^{2,3,15}$ yielded similar results, some studies have reported that years worked don't affect the frequency of low back pain. ${ }^{9}$ Considering that as the years worked increase, total exposure to risks that may cause musculoskeletal problems also increase, our study results are expected.

Smoking is reported to be a risk factor that increases the incidence of low back pain. ${ }^{16}$ In the present study, smokers had more low back pain than nonsmokers, yet the difference did not reach statistical significance. Karahan et $\mathrm{al}^{8}$, Daraiseh et $\mathrm{al}^{17}$, Vieira et $\mathrm{al}^{18}$ reported that smokers experienced low back pain more frequently and the difference was significant. Similar to our study, there are certain studies that found no statistically significant difference among smokers and non-smokers in terms of the frequency of low back pain but smokers experience more low back pain. ${ }^{2,15}$ Due to adverse effects of smoking on vascular system, blood circulation in spine and muscles are also negatively affected, making the musculoskeletal system more susceptible to external factors.

Regular exercise affects the individual positively both physically and mentally. It can especially prevent the development of musculoskeletal problems by strengthening the muscles. Similar to our study, Çil-Akıncı et $\mathrm{al}^{2}, \mathrm{Aksakal}^{\mathrm{at}} \mathrm{al}^{6}$, Yilmaz and Özkan ${ }^{3}$, Vieira, et $\mathrm{al}^{18}$ also found that nurses who exercised regularly experienced less low back pain.

Body mass index another individual factor that impacts the musculoskeletal system. In the present study, nurses with normal BMI were found to have more low back pain than overweight nurses. Even though Daraiseh et $\mathrm{al}^{17}$, Heuch et $\mathrm{al}^{19}$, Shiri et $\mathrm{al}^{20}$ reported that individuals with high BMI had higher incidence of low back pain, there are also studies ${ }^{6,9,13}$ that BMI causes no difference.

Repetitive movement, inappropriate posture and excessive force exertion are important factors causing musculoskeletal problems. ${ }^{16}$ In the present study, nurses who performed practices that may cause physical strain, including leaning, standing the same position for a long time, holding equipment for a long time, rotating backwards, lifting/carrying heavy medical equipment and pulling/pushing heavy medical equipment, more often in one shift experienced significantly more low back pain. Similarly, results of Çil-Akıncı et $\mathrm{al}^{2}$, Aksakal et $\mathrm{al}^{6}$, Alexopoulos et $\mathrm{al}^{7}$, Karahan et $\mathrm{al}^{8}$, Dlungwane et $\mathrm{al}^{12}$ are in concordance with our findings. 


\section{CONCLUSIONS}

In conclusion, it is recommended that operating room nurses should be trained about body mechanics, necessary steps should be taken to ensure adequate number of nurses in order to minimize the frequency of practices that may cause physical stress, acceptable break time in a shift should be provided to nurses when increasing the number of nurses is not possible, operating rooms should be arranged ergonomically and regular exercise programs should be organized to increase the endurance of lumbar muscles of operating room nurses.

Note: This study was presented (poster presentation) at "8th EORNA Congress" 4-7 May 2017, in Rhodes, GREECE.

\section{Conflict of Interest: None.}

Grant Support E Financial Disclosures: None.

\section{REFERENCES}

1. Kandemir D, Karaman A, Altun-Ugras G, Oztekin SD. Examination of Musculoskeletal Pain in Operating Room Nurses. HEAD. 2019;16(1):1-7. doi: 10.5222/HEAD.2019.001

2. Çil-Akınc1, Dereli E, Sert H. Low back pain among nurses working in Kırklareli and the associated factors. Acıbadem Uni Health Sci J. 2014;5(1):70-76.

3. Yilmaz E, Özkan S. Determination of the prevalence of low back pain among nurses working in hospitals. Turk J Phys Med Rehab. 2008;54(1):8-12.

4. Mohammadi M, Raiegani AAV, Jalali R, Ghobadi A, Salari $\mathrm{N}$. The prevalence of low back pain among Iranian hospital nurses: A systematic review and meta-analysis. Nursing and Midwifery Studies. 2019;8(1):1-6. doi: 10.4103/nms. nms $46 \_18$

5. Gul A, Ustundag H, Kahraman B, Purisa S. Evaluation of musculoskeletal pain among nurses. J Health Sci Prof. 2014;1(1):1-10.

6. Aksakal N, Ilhan MN, Yuksel H, Kurtcebe O, Bumin MA. Low back pain prevalence and related risk factors among nurses, medical assistants and porters in a university hospital. Turk J Occup Health Safety. 2015;9(32):38-46.

7. Alexopoulos EC, Tanagra D, Detorakis I, Gatsi P, Goroyia A, Michalopoulou M, et al. Knee and low back complaints in professional hospital nurses: Occurrence, chronicity, care seeking and absenteeism. Work. 2011;38(4):329-335. doi: 10.3233/WOR-2011-1136.

8. Karahan A, Kav S, Abbasoglu A, Dogan N. Low back pain: Prevalence and associated risk factors among hospital staff. J Adv Nurs. 2009;65(3):516-524. doi: 10.1111/j.13652648.2008.04905.x
9. Altınel L, Kose KC, Altınel EC. Profesyonel hastane çalısanlarında bel agrisi prevelansi ve bel agrisini etkileyen faktorler. Tip Arastirmalari Dergisi. 2007;5(3):115-520.

10. El-Soud AMA, El-Najjara AR, El-Fattaha NA, Hassanb AA. Prevalence of low back pain in working nurses in Zagazig University Hospitals: An epidemiological study. Egypt Rheumatol Rehabilit. 2014;41(3):109-115. doi: 10.4103/1110161X.140525

11. Shieh SH, Sung FC, Su CH, Tsai Y, Hsieh VCR. Increased low back pain risk in nurses with high workload for patient care: A questionnaire survey. Taiwanese J Obstet Gynecol. 2016;55(4):525-529. doi: 10.1016/j.tjog.2016.06.013

12. Dlungwane T, Voce A, Knight S. Prevalence and factors associated with low back pain among nurses at a regional hospital in KwaZulu-Natal, South Africa. Health SA Gesondheid. 2018;23(1):1-6. doi: 10.4102/hsag.v23i0.1082

13. Çınar-Medeni O, Elbasan B, Duzgun I. Low back pain prevalence in healthcare professionals and identification of factors affecting low back pain. J Back Musculoskeletal Rehabilit. 2017;30(3):451-459. doi: 10.3233/BMR-160571

14. June $\mathrm{KJ}$, Cho SH. Low back pain and work-related factors among nurses in intensive care units. J Clin Nurs. 2011;20(34):479-487. doi: 10.1111/j.1365-2702.2010.03210.x

15. Solak-Kabataş M, Kocuk M, Küçükler Ö. Evaluation of frequency and factors affecting low back pain in health care workers. Firat Uni Med J Health Sci. 2012;26(2);65-72.

16. Kose-Tosunoz IK, Oztunc G. Low back pain in nurses. Int J Caring Sci. 2017;10(3):1728-1732.

17. Daraiseh NM, Cronin SN, Davis LS, Shell RL, Karwowski $\mathrm{W}$. Low back symptoms among hospital nurses, associations to individual factors and pain in multiple body regions. Int J Indust Ergonomics. 2010;40(1):19-24. doi: 10.1016/j. ergon.2009.11.004

18. Vieira ER, Kumar S, Narayan Y. Smoking, no-exercise, overweight and low back disorder in welders and nurses. Int J Indust Ergonomics. 2008;38(2):143-149. doi: 10.1016/j. ergon.2006.02.001

19. Heuch I, Hagen K, Heuch I, Nygaard O, Zwart JA. The impact of body mass index on the prevalence of low back pain: The HUNT study. Spine. 2010;35(7):764-768. doi: 10.1097/BRS.0b013e3181ba1531

20. Shiri R, Karppinen J, Leino-Arjas P, Solovieva S, ViikariJuntura $\mathrm{E}$. The association between obesity and low back pain: A meta-analysis. American Journal of Epidemiology. 2010;171(2):135-154. doi: 10.1093/aje/kwp356.

\section{Authors Contribution:}

IC, AK, YO, AO: Conceived, designed and did statistical analysis \& editing of manuscript.

IC, AK, YO, AO: Did data collection and manuscript writing.

IC, AK, YO, AO: Did review, final approval of manuscript and are responsible for integrity of study. 